\title{
BENTUK TUTURAN DIREKTIF PADA GURU DALAM SITUASI PEMBELAJARAN BAHASA INDONESIA SISWA KELAS X MAN MALANG 1
}

\author{
Ratih Indah Sari \\ Magister Pendidikan Bahasa dan Sastra Indonesia \\ Universitas Muhammadiyah Malang \\ ratih.indah1991@gmail.com
}

\begin{abstract}
Abstrak: Penelitian ini mendeskripsikan bentuk tuturan direktif guru dalam pembelajaran bahasa Indonesia siswa kelas X MAN Malang 1. Jenis penelitian ini adalah kualitatif (qualitative research). Dalam penelitian ini bentuk datanya berupa kata, frasa, klausa dan kalimat. Sumber data pada penelitian ini adalah ujaran tindak tutur direktif yang diujarkan oleh guru dalam interaksi kelas sebagai bahan kajian untuk mengetahui penggunaan tindak tutur direktif guru dalam situasi pembelajaran. Teknik pengumpulan data dalam penelitian ini berupa rekam dan catat. Analisis data dalam penelitian ini menggunakan model Miles dan Huberman yang terdiri dari data reduction, data display, dan conclusion drawing/verification. Hasil penelitian menunjukkan bahwa bentuk tindak tutur direktif yang digunakan oleh guru meliputi (1) tindak tutur direktif requestives (meminta, mengemis, memohon, menekan, mengundang, mendoa, mengajak, mendorong), (2) tindak tutur direktif questions (bertanya, berinkuiri, menginterogasi), (3) tindak tutur direktif requirments (memerintah, menghendaki, mengomando, menuntut, mendikte, mengarahkan, menginstruksikan, mengantar, menyaratkan), (4) tindak tutur direktif prohibitives (melarang, membatasi), (5) tindak tutur direktif permissives (menyetujui, membolehkan, memberi wewenang, menganugerahi, mengabulkan, membiarkan, mengizinkan, melepaskan, memaafkan, memperkenankan), dan (6) tindak tutur direktif advisories (menasehatkan, memperingatkan, mengonseling, mengusulkan, menyarankan, mendorong).
\end{abstract}

Kata kunci: tuturan direktif, guru, pembelajaran bahasa Indonesia

Abstract: This study describing the directive speech of teacher during Indonesian language subject of $10^{\text {th }}$ grade students of Islamic Senior High School 1 Malang. This study applied qualitative research. Data of the study was in form of words, phrase, clause and sentences. The Data source was in the form of directive speech by the teacher during class interaction as review material to find out the application of directive speech used by teacher in learning situation. Data collection technique applied was in the record and log. Data analysis in this study used Miles and Huberman model comprised of data reduction, data display and conclusion drawing/verification. The result of the study showed that the directive speech used by teacher consisted of (1) directive-request speech (requesting, begging, emphasizing, inviting, offering prayer, urging, encouraging), (2) questions-directive speech (asking, inquiring, interrogating), (3) requirement-directive speech (demanding, dictating, leading, instructing, escorting, requiring), (4) prohibitive-directive speech (prohibiting, limiting), (5) permissive-directive speech (approving, allowing, authorizing, bestowing, granting, letting, permitting, apologizing, releasing, passing) and. (6) advisory-directive speech (suggesting, warning, counseling, proposing, advising, encouraging).

Keywords: directive speech, teacher, Indonesian language learning 


\section{PENDAHULUAN}

Bahasa itu merupakan fenomena yang selalu hadir dalam segala kegiatan manusia, digunakan oleh kelompok sosial yang berbeda untuk berbagai keperluan (Chaer, 2007: 15). Bahasa sebagai alat untuk menyampaikan ide, pikiran, hasrat dan keinginan kepada orang lain. Maksudnya ialah manusia dapat menyatakan ide, pikiran, hasrat dan keinginannya kepada orang lain dengan menggunakan bahasa, sehingga pesan yang disampaikan dapat dimengerti oleh orang lain. Penggunaan bahasa akan terus berkembang sesuai dengan perkembangan ilmu pengetahuan. Bahasa memiliki peran penting dari bahasa dalam kehidupan sehari-hari.

Menurut Keraf (Chaer, dan Agustina, 2004: 35) bahasa adalah alat komunikasi antara anggota masyarakat berupa simbol bunyi yang dihasilkan oleh alat ucap manusia. Pada komunikasi seharihari dalam konteks hubungan antara manusia yang satu dan manusia yang lainnya, sangatlah mustahil orang tidak bertemu dan berkontak ketika dia sedang melakukan aktivitas berbahasa dengan sesamanya (Rahardi, 2005: 2). Dalam komunikasi sehari-hari yang memerantikan bahasa manusia sebagai media pokok dipastikan selalu hadir dalam tingkat keseringan yang tinggi. Salah satu bentuk dari komunikasi ini ialah interaksi antar partisipan yang dimungkinkan oleh apa yang disebut fungsi-fungsi komunikatif bahasa. Fungsi-fungsi ini berubah-ubah sesuai dengan situasi. Menurut Dobson (dalam Ikhawati, 2010: 10) komunikasi bahasa memberikan tujuh fungsi bahasa yang terdiri atas (1) memberi dan menerima informasi, (2) proses menyatakan pikiran, (3) menyatakan pendapat, (4) membuat pertimbangan, (5) memengaruhi orang lain, (6) menyatakan perasaan pribadi, (7) interaksi secara sosial.

Menurut Searle (dalam Arifin, 1996: 10) dalam semua komunikasi bahasa terdapat tindak tutur. Ia berpendapat bahwa komunikasi bahasa bukan sekedar lambang, kata atau kalimat, tetapi akan lebih tepat apabila disebut produk atau hasil dari lambang, kata atau kalimat yang berwujud perilaku tindak tutur (the performance of speech $a c t$ ). Konsep tindak tutur pertama kali dicetuskan oleh Austin dalam bukunya How to Do Things with Word. Tindak tutur juga digunakan oleh guru untuk mentansfer ilmu kepada siswa. Guru menggunakan berbagai macam tindak tutur pada setiap pembelajaran sesuai dengan konteks tuturannya. Hal ini membuktikan bahwa peranan tindak tutur sangat penting dalam kehidupan sehari-hari.

Pada proses komunikasi guru merupakan ujung tombak pelaksana pendidikan di lapangan yang memegang peran penting. Hal ini terkait dengan keberhasilan dalam mencapai pengajaran keterampilan berbahasa, yang tidak luput dari tuturan guru, khususnya kompetensi guru bahasa Indonesia yang mencerminkan penggunaan bahasa Indonesia yang baik dan benar. Keberhasilan guru menciptakan suasana pelajaran yang kondusif, menciptakan suasana pembelajaran yang komunikatif, pemahaman guru terhadap siswa, perencanaan, perancangan, dan pelaksanaan pembelajaran, evaluasi hasil belajar, dan pengembangan siswa untuk mengaktualisasikan berbagai potensi yang dimilikinya. Hal ini merupakan salah satu kompetensi yang dimiliki guru yaitu kompetensi pedagogis.

Dalam proses pembelajaran juga tidak terlepas dari kompetensi yang dimiliki oleh guru dalam bentuk lain di antaranya (1) sosial ialah cara kemampuan guru berkomunikasi dan bergaul secara efektif dengan siswa, sesama pendidik, tenaga kependidikan, wali murid, dan masyarakat, (2) kepribadian ialah merupakan kemampuan personal yang mencerminkan kepribadian yang mantab, stabil dewasa, arif dan berwibawa, menjadi teladan bagi siswa, dan berakhlak mulia, (3) profesional ialah merupakan penguasaan materi pembelajaran secara luas dan mendalam, yang mencakup penguasaan materi kurikulum pembelajaran di sekolah dan substansi keilmuan yang menaungi materinya, serta penguasaan struktur dan metodologi 
keilmuannya.

Dari ketiga kompetensi tersebut, kompetensi yang sangat memegang peranan dalam penyelenggraan pembelajaran adalah komptensi sosial. Di mana komunikasi menjadi dasar bagi setiap individu untuk menjalin hubungan dengan siapa pun. Dalam konteks pembelajaran adalah hubungan guru dengansiswa, sesama pendidik, tenaga kependidikan, wali murid, dan masyarakat. Oleh karena itu, perlu kiranya guru sebagai sosok sentral dalam proses pembelejaran untuk menguasai tindak tutur yang akan digunakan dalam proses pembelajaran. Salah satu bentuk tindak tutur yang sering digunakan oleh guru adalah tindak tutur direktif. Tindak tutur direktif termasuk dalam tindak ilokusi yang berpijak pada fungsi tuturan. Tindak tutur direktif sebagai jenis tindak tutur yang dipakai oleh penutur untuk menyuruh orang lain melakukan sesuatu. Jenis tindak tutur ini menyatakan apa yang menjadi keinginan penutur, sedangkan menurut Searle (dalam Etikasari, 2012: 1) tindak tutur direktif merupakan tindak tutur yang bertujuan mengahasilkan suatu efek berupa tindakan yang dilakukan penutur.

Adapun klasifikasi tindak tutur direktif secara lebih rinci dipaparkan oleh Ibrahim (1993: 27), yaitu requertives, question, requierments, prohibitives, permissives, dan advisories. Requestive mengekspresikan keinginan atau harapan penutur), sehingga mitra tutur menyikapi keinginan yang mengekspresikan ini sebagai alasan (atau bagian dari alasan) untuk bertindak. Maksud perlokusi yang sesuai, sebagaimana yang akan terlihat, adalah bahwa mitra tutur menyikapi petutur benar-benar memiliki keinginan dan maksud yang dia ekspresikan dan bahwa mitra tutur melakukan tindakan yang diminta penutur. Verba requesting (permohonan) ini mempunyai konotasi yang bervariasi dalam kekuatan sikap yang diekspresikan, sebagaimana yang ada dalam "invite" (mengundang) dan "insist" (mendorong) dan di antara "ask" (meminta) dan "beg" (mengemis). Verba yang kuat mengandung pengertian kepentingan. "Baseech" (mendesak) dan "supplicate" (memohon), misalnya, merupakan penyampaian upaya untuk menarik simpati dalam performansi tertentu. Sebagian verba requesting memiliki skop yang lebih spesifik. "Memanggil" (atau "mengundang" secara sempit) mengacu pada permohonan terhadap permintaan agar mitra tutur datang; "beg" (mengemis) dan "solicit" (meminta) juga berlaku untuk permohonan yang berhubungan. Ia juga menyatakan bahwa meminta termasuk dalam bentuk direktif requestives yang berarti meminta dalam mengucapkan penutur memohon kepada mitra tutur apabila penutur mengekspresikan keinginan bahwa mitra tutur melakukan sesuatu sesuai yang dikehendaki oleh penutur dengan maksud bahwa mitra tutur melakukan sesuatu karena keinginan. Jadi, dalam pembelajaran di kelas guru menggunakan tuturan direktif permintaan tidak hanya sekadar memberitahukan sesuatu kepada mitar tuturnya, tetapi penutur juga bermaksud agar mitra tutur melakukan sesuatu seperti yang diinginkan oleh penutur. Permintaan disampaikan oleh guru yang memiliki kuasa atau hal yang diminta. Selain itu, agar permintaan dapat dikabulkan oleh orang yang dimintai, maka pemakaian tuturan direktif yang dituturkan oleh guru diawali dengan tolong. Penggunaan tuturan tindak tutur direktif ajakan muncul pada konteks mengerjakan soal latihan. Pada dasarnya tuturan direktif ajakan bermaksud untuk mengundang seseorang. Mendesak termasuk dalam bentuk direktif requestives, yaitu mengekspresikan keinginan penutur, sehingga mitra tutur melakukan sesuatu. Selain itu, mengekspresikan maksud penutur bahwa penutur mengaharapkan kepatuhan, sehingga mitra tutur menyikapi keinginan yang terekspresikan ini sebagai alasan untuk bertindak. Dalam tuturannya guru menggunakan awalan hayo yang divariasiakan menjadi ayo, serta penekanan frasa kunci berdasarkan materi pembelajaran siswa. Rahardi (2005: 100) berpendapat lazimnya kalimat desakan menggunakan awalan harus untuk memberikan penekanan maksud desakan tersebut. 
Ibrahim (1993: 30) menyatakan bahwa question (pertanyaan) merupakan requests permohonan di dalam kasus yang khusus, khusus dalam pengertian bahwa apa yang dimohon adalah, bahwa mitra tutur memberikan kepada penutur informasi tertentu. Terdapat perbedaan di antara pertanyaan-pertanyaan, tetapi tidak semuanya penting untuk taksonomi ilokusi. Juga terdapat pertanyaan ujian dan pertanyaan retoris. "Menginterogasi" juga mengandung sesuatu yang tidak terdapat dalam "menanyai". Di samping itu "quis" (menguji) dan "query" (menyelidik) tidak terlalu cocok untuk analisis kami, dalam pengertian bahwa keduanya tidak bisa digunakan untuk melaporkan isi pertanyaan itu tetapi hanya topiknya (Pt menguji Mt mengenai tipologi).

Ibrahim (1993: 231) menyatakan bahwa requirements (perintah), seperti menyuruh (ordering) dan mendikte (dictating), jangan sampai dirancukan dengan request (memohon), meskipun permohonan dalam pengertian yang kuat. Terdapat sebuah perbedaan penting di antara kedua perintah dan permohonan. Dalam requsting (memerintah), penutur mengekspresikan maksudnya sehingga mitra tutur menyikapi keinginan yang diekspresikan oleh penutur sebagai alasan untuk bertindak; dalam reqiurments (permohonan), maksud yang diekspresikan penutur adalah bahwa mitra tutur menyikapi ujaran petutur sebagai alasan untuk bertindak, dengan demikian ujaran penutur dijadikan sebagai alasan penuh untuk bertindak. Akibatnya, requiments tidak mesti melibatkan ekspresi keinginan penutur supaya mitra tutur bertindak dalam cara tertentu. Mungkin jelaslah bahwa penutur tidak bisa memberikan perhatian lebih, namun sebagai gantinya apa yang diekspresikan oleh petutur adalah kepercayaannya bahwa ujarannya mengandung alasan cukup bagi mitratutur untuk melakukan tindakan itu

Ibrahim(1993: 32) menyatakan prohibitives (larangan) bahwa larangan termasuk dalam bentuk tuturan direktif prohibitives yang artinya larangan, yaitu perintah/suruhan supaya mitra tutur tidak mengerjakan sesuatu. Biasanya, intonasi dari tuturan ini bersifat lebih tinggi dan dengan volume yang keras. Kesantunan pemakaian tuturan larangan yang dituturkan oleh guru dalam pembelajaran di kelas ditandai dengan penanda kesantunan jangan. Pemilihan penanda kesantunan ini dirasa lebih halus daripada pemakaian kata dilarang atau tidak boleh. Hal ini sesuai dengan pendapat Rahardi (2005: 109) yang menyatakan bahwa larangan dalam bahasa Indonesia, biasanya ditandai dengan penanda kata jangan. Siswa harus bisa bersikap disiplin karena hal tersebut penting. Guru dalam menjelaskan konsep materi pelajaran kepada siswa menggunakan tuturan direktif menyarankan kepada siswa terkait dengan materi yang dijelaskan agar siswa tidak mengalami kesalahan dalam memahami materi yang disampaikan. Guru tidak hanya sekadar menyampaikan sesuatu kepada siswa, tetapi guru juga bermaksud agar siswa melakukan sesuatu seperti yang diinginkan oleh guru.

Ibrahim (1993: 33) yang menyatakan bahwa menyarankan termasuk dalam bentuk advisories, yaitu menasihatkan, memperingatkan, mengkonseling, mengusulkan, menyarankan, dan mendorong yang artinya apa yang diekspresikan penutur bukanlah keinginan bahwa mitra tutur melakukan tindakan tertentu tetapi kepercayaan bahwa melakukan tindakan itu merupakan kepentingan mitra tutur. Dalam kegiatan pembelajaran menjelaskan konsep materi kepada siswa harus dilakukan agar siswa tidak mengalami kesalahan dalam memahami materi pelajaran. Hal tersebut sesuai dengan pendapat Hamalik (2009: 60) bahwa menyampaikan konsep perlu dilaksanakan guru karena dalam hal ini menyampaikan bahan baru kepada siswa berupa materi pembelajaran yang nantinya disertai dengan ilustrasi contoh. Penggunaan direktif bujukan dalam wacana kelas muncul pada waktu guru membuka pelajaran. Bujukan biasanya disisipi dengan rayuan agar mitra tuturnya agar mau melakukan sesuatu seperti yang diminta oleh penuturnya. Tuturan yang disampaikan oleh guru merupakan salah satu 
bentuk perhatian guru kepada siswa dengan mengucapkan salam dan menanyakan kabar siswa yang disampaikan dengan tuturan bujukan. Perhatian perlu diberikan kepada siswa agar siswa merasa termotivasi dalam kegiatan pembelajaran dan diakui keberdaannya di dalam kelas. Hamalik (2009: 196) menyatakan bahwa guru perannya tak terbatas sebagai pengajar saja, tetapi juga bertugas membantu siswa, mendorong mereka secara optimal dalam proses pembelajaran.

Dalam hal ini diharapkan kompetensi guru untuk menggunakan tindak tutur direktif dengan baik. Pada saat pelaksanaan interaksi belajar mengajar dalam kelas, sehingga pada saat situasi pembelajaran terlihat komunikatif. Berdasarkan pernyataan di atas peneliti memfokuskan pada penelitian tindak tutur direktif yang digunakan oleh guru dalam pembelajaran bahasa Indonesia di kelas. Penelitian tersebut difokuskan pada satu guru bahasa Indonesia yang berlatar belakang orang Jawa. Guru dalam kegiatan interaksi komunikasi menggunakan bahasa dalam proses pembelajaran. Komunikasi yang berlangsung antara guru dan siswa untuk memberitahukan perihal keadaan-keadaan tertentu, tuturan-tuturan tertentu dengan konteks tertentu yang terangkai dalam sebuah wacana.

Tindak tutur direktif merupakan salah satu wujud penggunaan bahasa sebagai sistem verbal yang dapat digunakan oleh guru untuk mengacu pada berbagai objek dan konsep dalam interaksi di kelas. Tindak tutur direktif merupakan bagian dari komunikasi yang digunakan guru dalam interaksi kelas. Tindak tutur direktif memiliki fungsi memerintah, meminta, mengizinkan, memberi saran, mengajak. Setiap fungsi dari tindak tutur direktif selalu digunakan oleh guru dalam proses pembelajaran. Hal ini yang akan dicari tahu bagaimana penggunaannya dan pemanfaatannya oleh guru dalam membangun komunikasi dalam proses pembelajaran.

\section{METODE}

Jenis penelitian yang digunakan dalam penelitian ini adalah kualitatif (Qualitative research) yaitu suatu penelitian yang ditujukan untuk mendiskripsikan dan menganalisis fenomena, orang, secara individual maupun kelompok. Data dihimpun dengan pengamatan yang seksama, mencakup deskripsi dalam konteks yang mendetil disertai catatan-catatan hasil wawancara yang mendalam, serta hasil analisis dokumen dan catatan-catatan (Sukmadinata, 2013: 60). Dalam penelitian ini bentuk datanya berupa kata, frasa, klausa dan kalimat. Sumber data pada penelitian ini adalah ujaran tindak tutur direktif yang diujarkan oleh guru dalam interaksi kelas sebagai bahan kajian penggunaan tindak tutur direktif guru dalam situasi pembelajaran. Teknik pengumpulan data dalam penelitian ini berupa rekam dan catat. Teknik rekam adalah teknik penjaringan data dengan merekam penggunaan bahasa, sedangkan teknik catat adalah teknik yang menjaring data dengan mencatat hasil penyimakan data pada kartu data (Kesuma, 2007: 45). Analisis data dalam penelitian ini menggunakan model Miles dan Huberman (Sugiyono, 2010: 337) yang terdiri dari data reduction, data display, dan conclusion drawing/verification.

\section{HASIL DAN PEMBAHASAN}

Tindak tutur direktif yang digunakan oleh guru bermacam-macam bentuknya yang meliputi (1) tindak tutur direktif requestives (meminta, mengemis, memohon, menekan, mengundang, mendoa, mengajak, mendorong), (2) tindak tutur direktif questions ( bertanya, berinkuiri, menginterogasi), (3) tindak tutur direktif requirments (memerintah, menghendaki, mengomando, menuntut, mendikte, mengarahkan, menginstruksikan, mengantar, mensyaratkan), (4) tindak tutur direktif prohibitives (melarang, membatasi), (5) tindak tutur direktif permissives (menyetujui, membolehkan, memberi wewenang, menganugerahi, mengabulkan, membiarkan, mengizinkan, melepaskan, memaafkan, memperkenankan), (6) tindak 
tutur direktif advisories (menasehatkan, memperingatkan, mengonseling, mengusulkan, menyarankan, mendorong). Pada analisis ini akan dikelompokkkan menjadi tiga bagian yaitu bagian awal, bagian inti, dan bagian akhir. Pembagian ini didasarkan pada kegiatan pembelajaran guru yang terjadi di dalam kelas.

\section{Bentuk Tuturan Direktif Requestives pada Kegiatan Awal (Meminta dan Mendorong)}

Hasil analisis membuktikan, dalam proses pembelajaran bahasa Indonesia siswa kelas $\mathrm{X}$ MAN Malang 1 guru memegang kendali interaksi kelas melalui tuturan yang diujarkan, salah satunya menggunakan tuturan direktif. Bentuk tuturan direktif yang pertama adalah requestives, merupakan bentuk tuturan yang diujarkan guru untuk meminta, mengemis, memohon, menekan, mengundang, mendoa, mengajak, dan mendorong. Pada penerapannya dalam proses pembelajaran di kegiatan awal guru hanya menggunakan bentuk tuturan requestives meminta. Berikut ini bentuk tuturan direktif requestives meminta yang digunakan oleh guru.

\section{(49) Konteks : Guru meminta siswa melepas jaket di dalam kelas. \\ TTD \\ : Jaketnya dilepas kalau di dalam kelas itu! (A/Dir $\left.{ }_{1} / \mathrm{F} / 2811\right)$}

Tuturan guru dalam data (49) di atas, menunjukkan guru meminta siswa untuk melepas jaket yang dikenakannya. Guru bermaksud menyuruh siswa untuk mematuhi peraturan, karena saat berada di kelas dalam situasi pembelajaran tidak diperbolehkan memakai jaket. Tuturan guru tersebut memberikan gambaran adanya bentuk tuturan direktif requestives yang kuat. Hal itu dibuktikan data (A/ $\left.\mathrm{Dir}_{1} / \mathrm{F} / 2811\right)$ dengan pilihan kata yang dianggap penting dilepas apabila diperhatikan kata ini dimaksudkan oleh guru untuk meminta siswa melepas jaket saat di dalam kelas. Pada kutipan di atas kata yang menjadi ikon adalah kata dilepas. Pemilihan kata ini dilakukan karena dari deretan kata dalam tuturan guru, kata inilah yang mempunyai peran besar dalam meminta siswa melepas jaketnya. Timbullah bentuk tuturan direktif requestives yang bertujuan menyuruh siswa untuk melepas jaketnya. Tuturan tersebut dituturkan oleh guru pada saat kegiatan apersepsi. Di bawah ini merupakan bentuk lain tuturan yang menggunakan bentuk direktif requestives untuk meminta siswa melakukan tindakan. Hal senada juga terdapat pada tuturan guru di bawah ini.

(50) Konteks : Guru meminta siswa untuk tenang.

TTD

$$
\begin{aligned}
& \text { Anak-anak pada kesempatan } \\
& \text { hari ini kita akan membahas } \\
& \text { tentang nilai-nilai kehidupan } \\
& \text { pada cerpen. Hustt harap anak- } \\
& \text { anak! (A/Dir } / \mathrm{F} / 2811)
\end{aligned}
$$

Tuturan guru dalam data (50) di atas, menunjukkan guru meminta siswa untuk tidak gaduh dalam pelajaran. Dalam tuturan tersebut guru mengatur kondisi kelas, agar saat pembelajaran berlangsung dapat terjadi situasi yang kondusif. Tuturan guru tersebut memberikan gambaran adanya bentuk tuturan direktif requestives yang kuat. Hal itu dibuktikan data $\left(\mathrm{A} / \mathrm{Dir}_{1} / \mathrm{F} / 2811\right)$ dengan pilihan kata yang dianggap penting harap dan tenang apabila diperhatikan kata ini dimaksudkan oleh guru untuk meminta siswa tidak gaduh. Pada kutipan di atas kata yang menjadi ikon adalah kata harap dan tenang. Pemilihan kata ini dilakukan karena dari deretan kata dalam tuturan guru, kata inilah yang mempunyai peran besar dalam meminta siswa untuk melakukan tindakan. Timbullah bentuk tuturan direktif requestives yang bertujuan menyuruh siswa untuk tidak gaduh dalam situasi pembelajaran. Tuturan tersebut dituturkan oleh guru pada saat kegiatan apersepsi. Hal senada juga terdapat pada tuturan guru di bawah ini. Tuturan tersebut dituturkan oleh guru pada saat memberi tahu kompetensi yang ingin dicapai. Berikut ini bentuk lain tuturan direktif requestives yang dituturkan oleh guru. 
(53) Konteks : Guru mendorong siswa lain untuk aktif dalam situasi pembelajaran.

TTD

: Yang lain? Nilai itu apa? (A/ $\operatorname{Dir}_{3} / \mathrm{F} / 2811$ )

Tuturan guru dalam data (53) di atas, menunjukkan guru mendorong siswa lain untuk aktif dalam situasi pembelajaran. Dalam tuturan tersebut guru mendorong/ mengajak siswa lain untuk berlomba-lomba menjawab pertanyaan yang diberikan oleh guru. Tuturan guru tersebut memberikan gambaran adanya bentuk tuturan direktif requestives yang kuat. Hal itu dibuktikan data (A/Dir $\left.{ }_{3} / \mathrm{F} / 2811\right)$ dengan pilihan kata yang dianggap penting yang dan lain apabila diperhatikan kata ini dimaksudkan oleh guru untuk meminta siswa menjawab pertanyaan. Pada kutipan di atas kata yang menjadi ikon adalah kata yang dan lain. Pemilihan kata ini dilakukan karena dari deretan kata dalam tuturan guru, kata inilah yang mempunyai peran besar dalam mendorong siswa untuk melakukan tindakan. Timbullah bentuk tuturan direktif requestives yang bertujuan mendorong siswa untuk menjawab pertanyaan. Tuturan tersebut dituturkan oleh guru pada saat kegiatan apersepsi.

\section{Bentuk Tuturan Direktif Questions pada Kegiatan Awal (Bertanya dan Menginterogasi)}

Pada proses pembelajaran bahasa Indonesia siswa kelas XMAN Malang 1 selain menggunakan bentuk requestives, guru juga menggunakan bentuk tuturan direktif questions. Bentuk tuturan direktif questions meliputi bertanya, berinkuiri, dan menginterogasi. Pada kegiatan awal bentuk tuturan direktif questions yang digunakan guru adalah questions menginterogasi dan bertanya. Penjelasan mengenai kedua bentuk tuturan yang digunakan oleh guru dalam tuturannya sebagai berikut.

(58) Konteks : Guru menginterogasi siswa

TTD : Nilai kehidupan, maksudnya apa nilai kehidupan dalam suatu karya satra? (A/Dir $2 / \mathrm{F} / 3011)$

Tuturan guru dalam data (58) di atas, menunjukkan guru menginterogasi jawaban yang diberikan oleh siswa. Dalam hal ini guru mengajarkan siswa untuk bertanggung jawab atas jawaban yang diberikan serta guru menguji sejauh mana pemahaman siswa terhadap materi yang telah diterima. Tuturan guru tersebut memberikan gambaran adanya bentuk tuturan direktif questions yang kuat. Hal itu dibuktikan data (A/Dir $/ 2 / 3011)$ dengan pilihan kaimat yang dianggap penting maksudnya dan apa apabila diperhatikan kalimat ini dimaksudkan oleh guru untuk menginterogasi siswa. Pada kutipan di atas kata yang menjadi ikon adalah kata maksudnya dan apa. Pemilihan kata ini dilakukan karena dari deretan kata dalam tuturan guru, kata inilah yang mempunyai peran besar dalam menginterogasi siswa agar bertanggung jawab atas jawaban yang telah diberikan. Timbullah bentuk tuturan direktif questions yang bertujuan meminta pertanggungjawaban dari jawaban yang diberikan siswa. Tuturan tersebut dituturkan oleh guru pada saat mendorong siswa untuk menjawab pertanyaan. Berikut ini bentuk lain dari tuturan direktif questions yang dituturkan oleh guru dalam situasi pembelajaran.

(59) Konteks : Guru bertanya pada siswa

$\begin{aligned} \text { TTD } & \text { Semalam apa ndak belajar? (A/ } \\ & \left.\operatorname{Dir}_{2} / \mathrm{F} / 612\right)\end{aligned}$

Tuturan guru dalam data (59) di atas, menunjukkan guru bertanya pada siswa. Dalam hal ini tuturan tersebut guru mempunyai makna bertanya pada siswa tentang kegiatan semalam, karena pada saat guru memberikan pertanyaan tentang materi kemarin siswa tidak dapat menjawab. Tuturan guru tersebut memberikan gambaran adanya bentuk tuturan direktif questions yang kuat. Hal itu dibuktikan data (A/Dir $/ 2 / 6 / 612)$ dengan pilihan kata yang dianggap penting apa apabila diperhatikan kalimat ini dimaksudkan 
oleh guru untuk bertanya pada siswa. Pada kutipan di atas kata yang menjadi ikon adalah kata apa. Pemilihan kata ini dilakukan karena dari deretan kata dalam tuturan guru, kata inilah yang mempunyai peran besar dalam bertanya pada siswa. Timbullah bentuk tuturan direktif questions yang bertujuan mendapatkan jawaban dari pertanyaan yang telah diberikan oleh guru. Tuturan tersebut dituturkan oleh guru pada saat kegiatan apersepsi dan motivasi.

\section{Bentuk Tuturan Direktif Requirments pada Kegiatan Awal (Memerintah, Mengomando, Menghendaki, Menginstruksikan)}

Pada proses pembelajaran di kelas, selain menggunakan bentuk tuturan direktif requestives dan questions guru juga menggunakan bentuk direktif lain yaitu requirments. Bentuk tuturan requirments adalah bentuk tuturan yang diujarkan guru untuk memerintah, menghendaki, mengomando, menuntut, mendikte, mengarahkan, mengistruksikan, mengantarkan, dan mensyaratkan. Pada penerapannya dalam proses pembelajaran guru tidak menggunakan semua bentuk tuturan requirments, guru hanya menggunakan empat bentuk requirments yaitu menghendaki, memerintahkan, menginstruksikan, dan mengomando. Berikut penjelasan bentuk tindak tutur direktif requirments yang digunakan oleh guru dalam situasi pembelajaran berupa.

(64) Konteks : Guru mengomando siswa TTD : Sudah mulai! (A/Dir $\left.{ }_{3} / \mathrm{F} / 3011\right)$

Tuturan guru dalam data (64) di atas, menunjukkan guru menuntut siswa agar tidak gaduh. Dalam hal ini guru memberi kode pada siswa agar siswa tidak gaduh dalam situasi pembelajaran. Tuturan guru tersebut memberikan gambaran adanya bentuk tuturan direktif requirments yang kuat. Hal itu dibuktikan dengan data (A/Dir $3 / \mathrm{F} / 3011)$ pilihan kaimat yang dianggap penting sudah dan mulai apabila diperhatikan kalimat ini dimaksudkan oleh guru mengomando siswa. Pada kutipan di atas kata yang menjadi ikon adalah kata sudah dan mulai. Pemilihan kata ini dilakukan karena dari deretan kata dalam tuturan guru, kata inilah yang mempunyai peran besar dalam memberi komando pada siswa. Timbullah bentuk tuturan direktif requirments yang bertujuan mengomando siswa dalam melakukan suatu tindakan. Tuturan tersebut dituturkan oleh guru pada saat memberi motivasi. Berikut ini bentuk lain tindak tutur direktif requirments yang dituturkan oleh guru dalam situasi pembelajaran.

(65) Konteks TTD

Guru menginstruksi siswa

: Sudah kita lanjut lagi. (A/ $\operatorname{Dir}_{3} / \mathrm{F} / 3011$ )

Tuturan guru dalam data (65) di atas, menunjukkan guru memberikan instruksi pada siswa. Dalam hal ini guru memberikan instruksi pada siswa agar siswa kembali fokus pada pelajaran, setelah guru memberi pengumuman. Tuturan guru tersebut memberikan gambaran adanya bentuk tuturan direktif requirments yang kuat. Hal itu dibuktikan pada data (A/ $\left.\operatorname{Dir}_{3} / \mathrm{F} / 3011\right)$ dengan pilihan kalimat yang dianggap penting lanjut apabila diperhatikan kalimat ini dimaksudkan oleh guru untuk memberi instruksi pada siswa. Pada kutipan di atas kata yang menjadi ikon adalah kata lanjut. Pemilihan kata ini dilakukan karena dari deretan kata dalam tuturan guru, kata inilah yang mempunyai peran besar dalam memberikan instruksi. Timbullah bentuk tuturan direktif requirments yang bertujuan mengajak siswa melakukan suatu tindakan. Tuturan tersebut dituturkan oleh guru pada saat akan memulai pelajaran. Berikut ini bentuk lain tindak tutur direktif requirments yang dituturkan oleh guru dalam situasi pembelajaran.

(66) Konteks : Guru memerintah siswa

TTD : Ini hari terakhir, inilah saat terakhir bagi kita. Hari ini kita membahas latian soal-soal 
UTS, nanti kalian pelajari. Ini silahkan dibagikan. (A/ $\operatorname{Dir}_{3} / \mathrm{B} / 412$ )

Tuturan guru dalam data (66) di atas, menunjukkan guru memerintakan siswa. Dalam hal ini guru memerintahkan siswa untuk membagikan latian soal-soal UTS dan mempelajari soal-soal latihan UTS. Tuturan tersebut dituturkan oleh guru pada saat kegiatan pembelajaran akan dimulai. Tuturan guru tersebut memberikan gambaran adanya bentuk tuturan direktif requirments yang kuat. Hal itu dibuktikan pada data (A/Dir $/ 3 / \mathrm{B} / 412)$ dengan pilihan kalimat yang dianggap penting silahkan dan dibagikan apabila diperhatikan kalimat ini dimaksudkan oleh guru untuk memerintah siswa melakukan tindakan. Pada kutipan di atas kata yang menjadi ikon adalah kata silahkan dan dibagikan. Pemilihan kata ini dilakukan karena dari deretan kata dalam tuturan guru, kata inilah yang mempunyai peran besar dalam memberi perintah pada siswa. Timbullah bentuk tuturan direktif requirments yang bertujuan memerintahkan siswa untuk membagikan soalsoal latihan UTS pada temannya. Tuturan tersebut dituturkan oleh guru pada saat akan memulai pelajaran. Berikut ini bentuk lain tindak tutur direktif requirments yang dituturkan oleh guru dalam situasi pembelajaran.

(68) Konteks : Guru menghendaki siswa segera mengumpulkan tugas.

TTD

: Sampai kapan saya harus menunggu kalian mengumpulkan tugas ini? (A/Dir $/$ /F/3011)

Tuturan guru dalam data (68) di atas, menunjukkan guru menghendaki siswa untuk segera mengumpulkan tugas. Dalam hal ini guru memberi dorongan pada siswa agar segera menyelesaikan tugasnya dan mengumpulkan tugas pada guru. Tuturan guru tersebut memberikan gambaran adanya bentuk tuturan direktif requirments yang kuat. Hal itu dibuktikan pada data $\left(\mathrm{A} / \mathrm{Dir}_{3} / \mathrm{F} / 3011\right)$ dengan pilihan kaimat yang dianggap penting sampai kapan saya harus menunggu kalian menggumpulkan tugas ini apabila diperhatikan kalimat ini dimaksudkan oleh guru menghendaki siswa segera mengumpulkan tugas. Pada kutipan di atas kata yang menjadi ikon adalah semua kata. Pemilihan kata ini dilakukan karena dari deretan kata dalam tuturan guru, kata inilah yang mempunyai peran besar dalam menghendaki siswa melakukan tindakan. Timbullah bentuk tuturan direktif requirments yang bertujuan siswa lain ikut aktif dalam pembelajaran. Tuturan tersebut dituturkan oleh guru pada saat kegiatan apersepsi dan motivasi. Berikut ini bentuk lain tindak tutur direktif requirments yang dituturkan oleh guru dalam situasi pembelajaran.

\section{Bentuk Direktif Advisories pada Kegiatan Awal (Memperingatkan)}

Bentuk direktif lain juga digunakan oleh guru dalam proses pembelajaran bahasa Indonesia siswa kelas X MAN Malang 1 yakni bentuk direktif advisories. Bentuk tuturan advisories meliputi, menasehatkan, memperingatkan, mengkonseling, dan mengusulkan. Hal ini dilakukan guru sesuai dengan maksud tuturan yang diinginkannya dalam situasi pembelajaran. Pada penerapannya guru tidak menggunakan semua bentuk tutursn direktif advisories, yang meliputi menasehati, memperingatkan, mengkonseling, dan mengusulkan, menyarankan serta mendorong. Pada penerapannya guru hanya menggunakan satu turan direktif advisories yaitu memperingatkan. Penggunaan bentuk tuturan direktif advisories diujarkan guru dalam kegiatan awal saat memberikan motivasi serta menasehati siswa sebelum memulai pelajaran. Berikut bentuk penerapan tindak tutur direktif advisories yang digunakan oleh guru berupa.

(69) Konteks : Guru memperingatkan siswa

TTD : Jadi tolong anak-anak terutama ini yang tidak terbiasa 
menyalakan lampu pada siang hari nanti jelas pasti kena, biar pun kamu mempunyai SIM dan STNK nanti kena tilang, ini salah satu butir hasil rapat kepala sekolah dan jajarannya di Polresta. Jadi nanti kamu kena tilang ya sudah kalau tidak membawa SIM dan STNK. Kendaraan akan disita dan diambil sendiri oleh orang tua kalian. Sorenya kalian akan diantarkan pulang para petugas, saya tidak membangun ketakutan kalian ini demi kebaikan kalian anak-anak jelas ya, termasuk yang biasa mengendarai kendaraan dengan kecepatan tinggi nanti disidik jari dan difoto terus suatu ketika kamu mengulang lagi jangan harap bisa membawa motor lagi ya, dah itu saja. (A/Dir 6 /F/3011)

Tuturan guru dalam data (69) di atas, menunjukkan guru memperingatkan siswa bahwa pihak kepolisian akan mengadakan operasi zebra khususnya untuk para pelajar yang tidak memiliki kelengkapan dalam bermotor. Dalam hal ini guru mengingatkan siswa agar mematuhi peraturan lalu lintas dan membiasakan menyalakan lampu pada siang hari saat mengendarai sepeda motor. Tuturan guru tersebut memberikan gambaran adanya bentuk tuturan direktif advisories yang kuat. Hal itu dibuktikan pada data (A/Dir 6 /F/3011) dengan pilihan kalimat yang dianggap penting tolong apabila diperhatikan kalimat ini dimaksudkan oleh guru untuk memperingatkan siswa. Pada kutipan di atas kata yang menjadi ikon adalah kata tolong. Pemilihan kata ini dilakukan karena dari deretan kata dalam tuturan guru, kata inilah yang mempunyai peran besar dalam tuturan untuk memperingatkan siswa agar melakukan/tidak melakukan suatu tindakan.
Timbullah bentuk tuturan direktif advisories yang bertujuan memperingatkan siswa agar mematuhi peraturan lalu lintas. Tuturan tersebut dituturkan oleh guru pada saat kegiatan pembelajaran akan dimulai.

\section{Bentuk Tuturan Direktif Requestives pada Kegiatan Inti (Meminta)}

Hasil analisis membuktikan, dalam proses pembelajaran bahasa Indonesia siswa kelas $\mathrm{X}$ MAN Malang 1 guru menggunakan berbagai macam tindak tutur salah satunya tuturan direktif. Pada kegiatan inti guru juga menggunakan bentuk tuturan direktif requestives. Bentuk tuturan requestives yakni meminta, mengemis, memohon, menekan, mengundang, mendoa, mengajak, dan mendorong. Namum pada proses pembelajaran dalam kegiatan inti guru hanya menggunakan bentuk requestives meminta. Hal ini dilakukan oleh guru untuk mengajak siswa lebih aktif dalam proses pembelajaran. Berikut bentuk tindak tutur direktif requestives yang digunakan oleh guru untuk meminta adalah sebagai berikut.

(72) Konteks : Guru meminta siswa membuka LKS.

TTD : Jadi fungsi suatu karya sastra itu bisa bernilai bisa bermanfaat. Anak-anak ini ada contoh di LKS halaman 44 contoh pada cerpen. Kemudian manfaat apa yang kita peroleh dari bacaan berikut ini. Silahkan dibuka LKSnya! (I/Dir $/$ /F/2811)

Tuturan guru dalam data (72) di atas, menunjukkan guru meminta siswa membuka LKS. Dalam hal ini guru menyuruh siswa untuk membuka LKS untuk melihat contoh pembahasan materi yang ditunjukkan oleh guru. Tuturan guru tersebut memberikan gambaran adanya bentuk tuturan direktif requestives yang kuat. Hal itu dibuktikan pada data (I/Dir $\left.{ }_{1} / \mathrm{F} / 2811\right)$ dengan 
pilihan kata yang dianggap penting silahkan apabila diperhatikan kalimat ini dimaksudkan oleh guru untuk meminta siswa melakukan tindakan. Pada kutipan di atas kata yang menjadi ikon adalah kata silahkan. Pemilihan kata ini dilakukan karena dari deretan kata dalam tuturan guru, kata inilah yang mempunyai peran besar dalam tuturan untuk meminta siswa tidak melakukan suatu tindakan. Timbullah bentuk tuturan direktif requestives yang bertujuan meminta siswa membuka LKS halaman 44. Tuturan tersebut dituturkan oleh guru pada saat kegiatan inti dimulai. Di bawah ini merupakan bentuk lain tuturan direktif requestives meminta. Hal senada juga terdapat pada tuturan guru dalam situasi pembelajaran di bawah ini.

(73) Konteks : Guru meminta siswa ke depan TTD : Ketuakelas sini! (I/Dir $\left.{ }_{1} / \mathrm{F} / 3011\right)$

Tuturan guru dalam data (73) di atas, menunjukkan guru meminta siswa untuk ke depan. Dalam hal ini guru memanggil ketua kelas untuk ke depan, untuk menerima tugas yang diberikan oleh guru. Tuturan guru tersebut memberikan gambaran adanya bentuk tuturan direktif requestives yang kuat. Hal itu dibuktikan pada data $\left(\mathrm{I} / \mathrm{Dir}_{1} / \mathrm{F} / 3011\right)$ dengan pilihan kata yang dianggap penting sini apabila diperhatikan kalimat ini dimaksudkan oleh guru untuk meminta siswa untuk ke depan. Pada kutipan di atas kata yang menjadi ikon adalah kata sini, pemilihan kata ini dilakukan karena dari deretan kata dalam tuturan guru, kata inilah yang mempunyai peran besar dalam tuturan untuk meminta siswa datang ke depan mendekati guru. Timbullah bentuk tuturan direktif requestives yang bertujuan memanggil ketua kelas. Tuturan tersebut dituturkan oleh guru pada saat kegiatan inti dimulai. Tuturan tersebut dituturkan oleh guru pada saat guru berperan sebagai fasilitator siswa dalam belajar.

\section{Tuturan Direktif Questions pada Kegiatan Inti (Bertanya dan Menginterogasi)}

Pada kegiatan inti guru juga menggunakan bentuk tuturan direktif dalam bentuk lain, yaitu bentuk tuturan direktif questions. Pada kegiatan inti guru menggunakan bentuk questions untuk bertanya, berinkuiri, dan menginterogasi siswa. Namun pada proses pembelajaran yang terjadi pada kegiatan inti guru hanya menggunakan questions (menginterogasi dan bertanya) tidak semua bentuk tuturan direktif questions dituturkan oleh guru. Berikut bentuk penerapan tindak tutur direktif questions yang digunakan oleh guru berupa.

(82) Konteks : Guru menginterogasi siswa TTD

$$
\begin{aligned}
& \text { : Mana ada namanya jam } \\
& \text { kosong! (I/Dir } / 2 / 2811)
\end{aligned}
$$

Tuturan guru dalam data (82) di atas, menunjukkan guru menginterogasi jawaban siswa. Dalam hal ini guru meminta penjelasan siswa atas jawaban dari pertanyaan "mengapa main kartu saat jam pelajaran berlangsung?" Tuturan guru tersebut memberikan gambaran adanya bentuk tuturan direktif questions yang kuat. Hal itu dibuktikan pada data ( $\left./ / \operatorname{Dir}_{2} / \mathrm{F} / 2811\right)$ dengan pilihan kata yang dianggap penting mana apabila diperhatikan kalimat ini dimaksudkan oleh guru untuk menginterogasi. Pada kutipan di atas kata yang menjadi ikon adalah kata mana. Pemilihan kata ini dilakukan karena dari deretan kata dalam tuturan guru, kata inilah yang mempunyai peran besar dalam tuturan sebagai penegas bahwa guru meminta pertanggungjawaban pada siswa. Timbullah bentuk tuturan direktif questions yang bertujuan menginterogasi. Tuturan tersebut dituturkan oleh guru pada saat guru berperan sebagai fasilitator siswa dalam belajar. Guru membiasakan siswa bertanggung jawab atas apa yang dituturkan. Berikut ini bentuk lain dari direktif questions guru dalam situasi pembelajaran. 
(83) Konteks : Guru bertanya pada siswa.

TTD : Ini siapa yang menulis kata jumat dikasih tanda petik? (I/ $\operatorname{Dir}_{2} / \mathrm{F} / 2811$ )

Tuturan guru dalam data (83) di atas, menunjukkan guru bertanya pada siswa. Dalam hal ini guru bertanya pada siswa siapa yang menulis kata Jumat salah dalam jurnal, guru mengajarkan rasa tanggung jawab pada siswa. Pada konteks di atas guru bertanya pada siswa siapa yang menulis kata "Jumat" salah, guru mengajarkan rasa tanggung jawab pada siswa. Tuturan guru tersebut memberikan gambaran adanya bentuk tuturan direktif questions yang kuat. Hal itu dibuktikan pada data (I/Dir $/ 2 / \mathrm{F} / 2811)$ dengan pilihan kalimat yang dianggap penting siapa apabila diperhatikan kalimat ini dimaksudkan oleh guru untuk bertanya. Pada kutipan di atas kata yang menjadi ikon adalah siapa. Pemilihan kata ini dilakukan karena dari deretan kata dalam tuturan guru, kata inilah yang mempunyai peran besar dalam tuturan kalimat tanya, yang mengharapkan jawaban seseorang/nama orang. Timbullah bentuk tuturan direktif questions yang bertujuan mendapatkan jawaban dari apa yang ditanyakan pada siswa. Tuturan tersebut dituturkan oleh guru pada saat siswa mengerjakan tugas dari guru.

\section{Bentuk Tuturan Direktif Requirments pada Kegiatan Inti (Memerintah, Mengarahkan, Menginstruksikan, dan Memperingatkan)}

Dalam proses pembelajaran pada kegiatan inti, guru menggunakan bermacam-macam bentuk tuturan direktif, salah satunya adalah requirments. Pengklasifikasian requirments itu sendiri dibagi menjadi beberapa macam yaitu, memerintah, menghendaki, mengomando, menuntut, mendikte, mengarahkan, menginstruksikan, mengantar, dan mensyaratkan. Pada penerapan dalam proses pembelajaran bahasa Indonesia siswa kelas X MAN Malang 1 guru tidak menggunakan semua bentuk requirments. Guru hanya menggunakan bentuk direktif requirments (menghendaki, mengarahkan, mengistruksi, dan memerintah). Berikut bentuk tindak tutur direktif requirments yang digunakan oleh guru dalam situasi pembelajaran.

(92) Konteks : Guru mengarahkan siswa.

TTD

$$
\begin{aligned}
& \text { Kalian saja kalau terlambat } \\
& \text { datang ke sekolah saja gerbang } \\
& \text { ditutup kok, minta surat izin. } \\
& \text { Sudah sekarang ke guru piket } \\
& \text { sana. Bu mu minta surat. (I/ } \\
& \operatorname{Dir}_{3} / \mathrm{F} / 2811 \text { ) }
\end{aligned}
$$

Pada konteks (92) di atas guru mengarahkan siswa yang terlambat masuk ke kelas untuk pergi ke guru piket minta surat izin masuk kelas. Tuturan guru tersebut memberikan gambaran adanya bentuk tuturan direktif requirments yang kuat. Hal itu dibuktikan pada data (A/Dir $/$ /F/2811) dengan pilihan kalimat yang dianggap penting sekarang apabila diperhatikan kalimat ini dimaksudkan oleh guru untuk mengarahkan siswa. Pada kutipan di atas kata yang menjadi ikon adalah sekarang. Pemilihan kata ini dilakukan karena dari deretan kata dalam tuturan guru, kata inilah yang mempunyai peran besar, penggunaan kata sekarang dianggap tepat karena memiliki fungsi mengarahkan. Timbullah bentuk tuturan direktif questions yang bertujuan menyuruh siswa melakukan tindakan sesuai dengan arahan yang diberikan oleh guru. Tuturan tersebut dituturkan oleh guru pada saat proses pembelajaran sedang terjadi. Di bawah ini bentuk lain tuturan direktif questions yang dituturkan oleh guru dalam situasi pembelajaran.

(93) Konteks : Guru memberi instruksi siswa. TTD Sudah kita lanjutkan, dengan
adanya nilai kehidupan dari
cerpen bisa mempengaruhi
pembaca. $\left(\mathrm{I} / \mathrm{Dir}_{5} / \mathrm{F} / 2811\right)$

Pada konteks (93) di atas guru memperkenankan siswa untuk bertanya tentang materi yang belum dipahami oleh siswa. Tuturan 
guru tersebut memberikan gambaran adanya bentuk tuturan direktif requirments yang kuat. Hal itu dibuktikan pada data ( $\left.\mathrm{I} / \mathrm{Dir}_{5} / \mathrm{F} / 2811\right)$ dengan pilihan kalimat yang dianggap penting lanjutkan apabila diperhatikan kalimat ini dimaksudkan oleh guru untuk menginstruksi siswa. Pada kutipan di atas kata yang menjadi ikon adalah lanjutkan. Pemilihan kata ini dilakukan karena dari deretan kata dalam tuturan guru, kata inilah yang mempunyai peran besar, penggunaan kata lanjutkan dianggap tepat karena memiliki fungsi memberikan sebuah instruksi pada siswa. Timbullah bentuk tuturan direktif requirments yang bertujuan menyuruh siswa untuk kembali fokus dalam pelajaran. Tuturan tersebut dituturkan oleh guru pada saat proses pembelajaran sedang terjadi. Berikut ini bentuk lain tindak tutur direktif requirments yang dituturkan oleh guru dalam situasi pembelajaran.

(95) Konteks : Guru memberi perintah pada siswa

TTD

: Baiklah sekarang kalian kerjakan tugas pada halaman 43 untuk mempertajam materi hari ini bagian A no sampai 5 saya tunggu 10 menit. (I/ $\left.\mathrm{Dir}_{3} / \mathrm{F} / 3011\right)$.

Pada konteks (95) di atas guru memerintahkan siswa untuk mengerjakan LKS sesuai dengan ketentuan waktu yang dibuat oleh guru. Guru memerintahkan siswa untuk mengerjakan latihan soal setelah menerima materi dari guru. Tuturan guru tersebut memberikan gambaran adanya bentuk tuturan direktif requirments yang kuat. Hal itu dibuktikan pada data (I/Dir $\left.{ }_{3} / \mathrm{F} / 3011\right)$ dengan pilihan kalimat yang dianggap penting kerjakan apabila diperhatikan kalimat ini dimaksudkan oleh guru untuk memerintahkan siswa melakukan sesuatu. Pada kutipan di atas kata yang menjadi ikon adalah kerjakan semangat. Pemilihan kata ini dilakukan karena dari deretan kata dalam tuturan guru, kata inilah yang mempunyai peran besar dalam memerinta siswa, dengan menggunakan kata kerjakan siswa diminta untuk melakukan suatu tindakan. Timbullah bentuk tuturan direktif requirments yang bertujuan memerintahkan siswa untuk mengerjakan latihan soal. Tuturan tersebut dituturkan oleh guru pada saat pelajaran sedang berlangsung. Berikut ini bentuk lain tindak tutur direktif requirments yang dituturkan oleh guru dalam situasi pembelajaran.

(96) Konteks : Guru memeringatkan siswa tentang materi pembelajaran.

TTD : Jangan sampai anak-anak kalian menyebutkan sudut pandang orang kedua. Ini harus kalian pahami betul karena akan berkaitan hingga kelas 3 nanti. (I/Dir $\left.6{ }_{6} / \mathrm{F} / 3011\right)$

Tuturan guru pada konteks (96) di atas guru memeringatkan siswa, agar mengingat dan memahami tentang materi sudut pandang, karena akan dibahas lagi di kelas 3. Tuturan guru tersebut memberikan gambaran adanya bentuk tuturan direktif requirments yang kuat. Hal itu dibuktikan pada data ( $\left./ / \operatorname{Dir}_{6} / \mathrm{F} / 3011\right)$ dengan pilihan kata yang dianggap penting jangan apabila diperhatikan kalimat ini dimaksudkan oleh guru untuk memeringatkan siswa. Guru meminta siswa untuk benar-benar memahami semua materi yang telah diajarkan. Pada kutipan di atas kata yang menjadi ikon adalah jangan. Pemilihan kata ini dilakukan karena dari deretan kata dalam tuturan guru, kata inilah yang mempunyai peran besar dalam melarang/memeringatkan siswa terhadap tindakan tertentu. Timbullah bentuk tuturan direktif requirments yang bertujuan meminta siswa memahami materi. Tuturan tersebut dituturkan oleh guru pada saat pelajaran sedang berlangsung. 


\section{Bentuk Tuturan Direktif Prohibitives pada Kegiatan Inti (Melarang)}

Dalam kegiatan inti guru juga menggunakan bentuk direktif prohibitives dalam bertutur. Tuturan prohibitives digunakan guru untuk membatasi dan melarang siswa melakukan sesuatu tindakan. Dalam proses pembelajaran di kelas X MAN Malang I guru hanya ditemukan satu bentuk tindak tutur diretif, yaitu tuturan direktif prohibitives melarang. Berikut bentuk tindak tutur direktif prohibitives yang digunakan oleh guru dalam situasi pembelajaran.

(101) Konteks : Guru melarang siswa ke kantin Siswa : Pak izin ke belakang ya?

Guru : Iya, mana dompetnya bawa sini dulu

Siswa : Ada di tas pak

Guru : Jangan ke kantin lo ya! (I/ $\operatorname{Dir}_{4} / \mathrm{F} / 612$ )

Tuturan guru pada konteks (101) di atas guru melarang siswa untuk pergi ke kantin saat siswa izin pergi ke belakang. Tuturan tersebut dituturkan oleh guru pada saat pelajaran berlangsung, guru memberi izin pada siswa yang izin pergi ke belakang. Guru berpesan pada siswa agar tidak pergi ke kantin. Tuturan guru tersebut memberikan gambaran adanya bentuk tuturan direktif prohibitives yang kuat. Hal itu dibuktikan pada data (I/Dir $/$ /F/612) dengan pilihan kata yang dianggap penting jangan apabila diperhatikan kalimat ini dimaksudkan oleh guru untuk melarang siswa melakukan suatu hal. Pada kutipan di atas kata yang menjadi ikon adalah jangan. Pemilihan kata ini dilakukan karena dari deretan kata dalam tuturan guru, kata inilah yang mempunyai peran besar dalam melarang/ memeringatkan siswa terhadap tindakan tertentu. Timbullah bentuk tuturan direktif requirments yang bertujuan meminta siswa memahami materi. Tuturan tersebut dituturkan oleh guru pada saat pelajaran sedang berlangsung.

\section{Bentuk Tuturan Direktif Permissives pada Kegiatan Inti (Memberi Wewenang, Menganugerahi, Mengizinkan)}

Pada proses pembelajaran guru juga menggunakan bentuk direktif permissives, yang merupakan salah satu bentuk tuturan direktif. Bentuk direktif permissives meliputi menyetujui, membolehkan, memberi wewenang, menganugerahi, mengabulkan, memberikan wewenang, membiarkan, melepaskan, memaafkan, dan memperkenankan. Dalam proses pembelajaran di kelas X MAN Malang 1 guru hanya menerapkan bentuk permissives memberi wewenang saja. Berikut bentuk tindak tutur direktif permissives yang digunakan oleh guru dalam situasi pembelajaran.

(103) Konteks : Guru menerangkan materi pada siswa

TTD

: Betul menggandaikan emasnya. Nah demikian halnya dengan sastra anak-anak baik itu novel, cerpen, roman dan sebagainya itu pasti mengandung nilai-nilai kehidupan. Mengandung nilai baik pada pengarang maupun pada pembaca. Saya ulang lagi anak-anak jadi fungsi suatu karya sastra itu bisa bernilai dan bermanfaat bagi pembaca serta menghibur. Contohnya yang menghibur jika kalian sedang galau terus kalian membaca cerpen atau novel yang kalian sukai otomatis kalian merasa terhibur. (I/ $\operatorname{Dir}_{5} / \mathrm{F} / 2811$ )

Tuturan guru pada konteks (103) di atas guru memberi wewenang pada siswa untuk mendapatkan materi dalam pembelajaran. Tuturan guru tersebut memberikan gambaran adanya bentuk tuturan direktif permissives yang kuat. Hal itu dibuktikan pada data (I/ 
$\mathrm{Dir}_{5} / \mathrm{F} / 2811$ ) dengan pilihan kata yang dianggap penting betul apabila diperhatikan kalimat ini dimaksudkan oleh guru untuk menjelaskan materi. Pada kutipan di atas kata yang menjadi ikon adalah betul. Pemilihan kata ini dilakukan karena dari deretan kata dalam tuturan guru, kata inilah yang mempunyai peran besar untuk meyakinkan siswa dalam menyampaikan materi. Timbullah bentuk tuturan direktif permissives yang bertujuan menyampaikan materi pada siswa. Tuturan tersebut dituturkan oleh guru pada saat pelajaran sedang berlangsung. Tuturan tersebut dituturkan oleh guru pada saat pelajaran berlangsung. Berikut ini bentuk lain tindak tutur direktif permissives yang dituturkan oleh guru.

(104) Konteks : Guru memuji siswa.

TTD

: Kata penghubung, pinter sekali kalian, Semoga mendapat nilai yang baik. (I/Dir $\left.{ }_{5} / \mathrm{B} / 412\right)$

Tuturan guru pada konteks (104) di atas guru menganugerahi pujian pada siswa karena dapat menjawab pertanyaan dari guru, hal ini sebagai penyemangat siswa dalam pelajaran. Tuturan guru tersebut memberikan gambaran adanya bentuk tuturan direktif permissives yang kuat. Hal itu dibuktikan pada data $\left(\mathrm{I} / \mathrm{Dir}_{5} / \mathrm{B} / 412\right)$ dengan pilihan kalimat yang dianggap penting pinter apabila diperhatikan kalimat ini dimaksudkan oleh guru untuk menganugerahi. Pada kutipan di atas kata yang menjadi ikon adalah pintar. Pemilihan kata ini dilakukan karena dari deretan kata dalam tuturan guru, kata inilah yang mempunyai peran besar untuk memberikan pujian pada siswa. Timbullah bentuk tuturan direktif permissives yang bertujuan memuji. Tuturan tersebut dituturkan oleh guru pada saat pelajaran sedang berlangsung. Berikut ini bentuk lain tindak tutur direktif permissives yang dituturkan oleh guru dalam situasi pembelajaran.

(105) Konteks : Guru memberi memberi izin siswa.

Siswa : Pak izin ke belakang ya?

Guru : Iya. (I/Dir $\left.{ }_{5} / \mathrm{F} / 612\right)$
Tuturan guru pada konteks (105) di atas guru mengizinkan siswa yang ingin pergi ke belakang. Tuturan guru tersebut memberikan gambaran adanya bentuk tuturan direktif permissives yang kuat. Hal itu dibuktikan pada data (I/Dir $\left.{ }_{5} / \mathrm{F} / 612\right)$ dengan pilihan kata yang dianggap penting iya apabila diperhatikan kalimat ini dimaksudkan oleh guru untuk mengizinkan. Pada kutipan di atas kata yang menjadi ikon adalah iya. Pemilihan kata ini dilakukan karena dari deretan kata dalam tuturan guru, kata inilah yang mempunyai peran besar untuk memberi izin siswa yang hendak ke belakang. Timbullah bentuk tuturan direktif permissives yang bertujuan memberi izin. Tuturan tersebut dituturkan oleh guru pada saat pelajaran sedang berlangsung.

\section{Bentuk Tuturan Direktif Advisories pada Kegiatan Inti (Memeringatkan)}

Pada proses pembelajaran disamping itu guru juga menggunakan bentuk direktif advisories yang merupakan bentuk direktif terakhir. Bentuk direktif advisories meliputi menasehati, memperingatkan, mengkonseling, mengusulkan, menyarankan, dan mendorong. Dalam proses pembelajaran di kelas X MAN Malang 1 guru hanya menerapkan bentuk advisories memeringatkan. Berikut ini bentuk tindak tutur direktif advisories yang digunakan oleh guru dalam situasi pembelajaran.

(108) Konteks : Guru memeringatkan siswa. TTD : Awas kalo pancet Zen!
Zen duduk sini. (I/Dir $/ \mathrm{F} / 2811)$

Tuturan guru pada konteks (108) di atas guru memperingatkan siswa agar tidak melakukan kesalahannya lagi. Tuturan guru tersebut memberikan gambaran adanya bentuk tuturan direktif adviesories yang kuat. Hal itu dibuktikan pada data (I/Dir 6 /F/2811) dengan pilihan kata yang dianggap penting awas apabila diperhatikan kalimat ini dimaksudkan oleh guru untuk memeringatkan. Pada kutipan di atas kata yang menjadi ikon adalah awas. Pemilihan kata ini 
dilakukan karena dari deretan kata dalam tuturan guru, kata inilah yang mempunyai peran besar memperingatkan siswa. Timbullah bentuk tuturan direktif advisories yang bertujuan melarang siswa mengulangi perbuatannya lagi. Tuturan tersebut dituturkan oleh guru pada saat pelajaran sedang berlangsung. Berikut bentuk direktif adviesories yang lain dalam situasi pembelajaran.

(109) Konteks : Guru memeringatkan siswa.

TTD

: He dengan teman manggilnya sampean, jangan koen, kata koen itu kasar anak-anak kalau gak sampen anda! (I/ $\operatorname{Dir}_{6} / \mathrm{B} / 412$ )

Tuturan guru pada konteks (109) di atas guru memperingatkan siswa agar sesama teman kalau menyapa dengan kata sampean. Tuturan guru tersebut memberikan gambaran adanya bentuk tuturan direktif adviesories yang kuat. Hal itu dibuktikan pada data (I/Dir $/ \mathrm{F} / 2811$ ) dengan pilihan kata yang dianggap penting he dengan teman manggilnya sampean, jangan koen, kata koen itu kasar anak-anak kalau gak sampean anda. Apabila diperhatikan kalimat ini dimaksudkan oleh guru untuk memeringatkan. Pada kutipan di atas kata yang menjadi ikon adalah semua kata. Pemilihan kata ini dilakukan karena dari deretan kata dalam tuturan guru, kalimat inilah yang mempunyai peran besar memeringatkan siswa. Timbullah bentuk tuturan direktif advisories yang bertujuan mengingatkan siswa dan memberi contoh yang baik pada siswa. Tuturan tersebut dituturkan oleh guru pada saat pelajaran sedang berlangsung.

\section{Bentuk Tuturan Direktif Requestives pada Kegiatan Akhir (Meminta)}

Hasil analisis membuktikan dalam proses pembelajaran bahasa Indonesia siswa kelas X MAN Malang 1 pada kegiatan akhir guru menggunakan berbagai macam tindak tutur, salah satunya tuturan direktif. Pada kegian inti guru juga menggunakan bentuk tuturan direktif requestives.
Bentuk tuturan requestives yakni meminta, mengemis, memohon, menekan, mengundang, mendoa, mengajak, dan mendorong. Namum pada proses pembelajaran dalam kegiatan inti guru hanya menggunakan bentuk requestives meminta. Berikut bentuk tindak tutur direktif requestives yang digunakan oleh guru untuk meminta adalah sebagai berikut.

(115) Konteks : Guru meminta siswa untuk mempersiapkan diri menhadapi UAS.

TTD

: Tolong ketika ujian diperhatikan baik-baik jangan ragu-ragu dalam menjawab, ingat nilai semester ini berpengaruh. $\left(\mathrm{Akh} / \mathrm{Dir}_{1} / \mathrm{F} / 412\right)$

Tuturan guru pada konteks (115) di atas guru meminta siswa untuk belajar mempersiapkan diri menghadapi UAS serta tidak ragu-ragu dalam mengerjakan soal dan mendapat nilai yang memuaskan. Dalam tuturan tersebut guru menginginkan siswa untuk mempersiapkan diri menghadapi ujian akhir sekolah dan mendapatkan nilai yang memuaskan. Tuturan guru tersebut memberikan gambaran adanya bentuk tuturan direktif requestives yang kuat. Hal itu dibuktikan pada data $\left(\mathrm{Akh} / \mathrm{Dir}_{1} / \mathrm{F} / 412\right)$ dengan pilihan kata yang dianggap penting tolong, apabila diperhatikan kalimat ini dimaksudkan oleh guru untuk meminta siswa melakukan tindakan. Pada kutipan di atas kata yang menjadi ikon adalah tolong. Pemilihan kata ini dilakukan karena dari deretan kata dalam tuturan guru, kata inilah yang mempunyai peran besar untuk meminta siswa agar tidak ragu-ragu dalam menjawab soal ujian, sehingga timbullah bentuk tuturan direktif requetivesives yang bertujuan meminta siswa melakukan tindakan. Tuturan tersebut dituturkan oleh guru pada saat pelajaran sedang berlangsung.

\section{Bentuk Tuturan Direktif Questions pada Kegiatan Akhir (Bertanya)}

Pada kegiatan akhir guru juga menggunakan 
bentuk tuturan direktif dalam bentuk lain, yaitu bentuk tuturan direktif questions. Pada kegiatan inti guru menggunakan bentuk questions untuk bertanya, berinkuiri, dan menginterogasi siswa. Namun pada proses pembelajaran yang terjadi pada keegiatan inti guru hanya menggunakan questions bertanya tidak semua bentuk tuturan direktif questions dituturkan oleh guru. Berikut bentuk penerapan tindak tutur direktif questions yang digunakan oleh guru berupa.

(117) Konteks : Guru bertanya pada siswa

TTD : Siapa yang jadi ketua kelas? $\left(\mathrm{Akh} / \mathrm{Dir}_{1} / \mathrm{F} / 2811\right)$

Tuturan guru pada konteks (117) di atas guru bertanya pada siswa siapa yang menjadi ketua kelas. Dalam tuturan tersebut guru bertanya pada siswa, karena guru meminta ketua kelas yang memimpin doa sebelum pulang. Tuturan guru tersebut memberikan gambaran adanya bentuk tuturan direktif questions yang kuat. Hal itu dibuktikan pada data (Akh/Dir $/ \mathrm{F} / 2811)$ dengan pilihan kalimat yang dianggap penting siapa apabila diperhatikan kalimat ini dimaksudkan oleh guru bertanya. Pada kutipan di atas kata yang menjadi ikon adalah siapa. Pemilihan kata ini dilakukan karena dari deretan kata dalam tuturan guru, kata inilah yang mempunyai peran besar dalam tuturan kalimat tanya, yang mengharapkan jawaban seseorang/nama orang. Timbullah bentuk tuturan direktif questions yang bertujuan mendapatkan jawaban dari apa yang ditanyakan pada siswa. Tuturan tersebut dituturkan oleh guru pada saat siswa mengerjakan tugas dari guru.

\section{Bentuk Tuturan Direktif Requirments pada Kegiatan Akhir (Memerintah dan Menginstruksikan)}

Pada proses pembelajaran di kelas, dalam kegiatan akhir selain menggunakan bentuk tuturan direktif requestives dan questions guru juga menggunakan bentuk direktif lain yaitu requirments. Bentuk tuturan requirments adalah bentuk tuturan yang diujarkan guru untuk memerintah, menghendaki, mengomando, menuntut, mendikte, mengarahkan, mengistruksikan, mengantarkan, dan mensyaratkan. Pada penerapannya dalam proses pembelajaran guru tidak menggunakan semua bentuk tuturan requirments, guru hanya menggunakan dua bentuk requirments yaitu memerintahkan dan menginstruksikan. Berikut penjelasan bentuk tindak tutur direktif requirments yang digunakan oleh guru dalam situasi pembelajaran berupa.

(118) Konteks : Guru memberi instruksi pada siswa.

TTD

: Ya sudah berdoa dulu. (Akh/ $\operatorname{Dir}_{1} / \mathrm{F} / 3011$ )

Tuturan guru pada konteks (118) di atas guru memberikan instruksi pada siswa agar berdoa sebelum mereka pulang. Tuturan guru tersebut dituturkan pada saaat siswa ingin cepat-cepat keluar kelas untuk pulang setelah mendengar bel sekolah berbunyi. Tuturan guru tersebut memberikan gambaran adanya bentuk tuturan direktif requirments yang kuat. Hal itu dibuktikan pada data (Akh/Dir $/$ /F/3011) dengan pilihan kalimat yang dianggap penting ya sudah berdoa dulu, apabila diperhatikan kalimat ini dimaksudkan oleh guru untuk menginstruksi. Pada kutipan di atas kata yang menjadi ikon adalah semua kata. Pemilihan kata ini dilakukan karena dari deretan kata dalam tuturan guru, kalimat inilah yang mempunyai peran besar dalam memberikan instruksi. Timbullah bentuk tuturan direktif requirments yang bertujuan menyuruh siswa agar berdoa terlebih dahulu. Tuturan tersebut dituturkan oleh guru pada saat kegiatan akhir sebelum pulang. Berikut bentuk lain dari tuturan direktif requirments dalam situasi pembelajaran.

(119) Konteks : Guru memerintah siswa.

TTD : Sekarang berdoa! (Akh/ $\mathrm{Dir}_{3} / \mathrm{F} / 412$ )

Pada konteks (119) di atas guru memerintahkan siswa untuk segera berdoa 
sebelum mereka pulang. Guru menanamkan siswa untuk memiliki karakter religius. Tuturan guru tersebut memberikan gambaran adanya bentuk tuturan direktif requirments yang kuat. Hal itu dibuktikan pada data $\left(\mathrm{Akh}_{\mathrm{Dir}} / \mathrm{F} / 412\right)$ dengan pilihan kalimat yang dianggap penting sekarang, apabila diperhatikan kalimat ini dimaksudkan oleh guru untuk memerintah. Pada kutipan di atas kata yang menjadi ikon adalah sekarang. Pemilihan kata ini dilakukan karena dari deretan kata dalam tuturan guru, kalimat inilah yang mempunyai peran besar untuk menunjukkan bahwa guru memerintahkan siswa untuk berdoa. Timbullah bentuk tuturan direktif requirments yang bertujuan menyuruh siswa agar berdoa terlebih dahulu. Tuturan tersebut dituturkan oleh guru pada saat kegiatan akhir sebelum pulang.

\section{Bentuk Tuturan Direktif Advisories pada Kegiatan Akhir (Menasehatkan)}

Pada proses pembelajaran disamping itu guru juga menggunakan bentuk direktif advisories yang merupakan bentuk direktif terakhir. Bentuk direktif advisories meliputi menasehati, memeringatkan, mengonseling, mengusulkan, menyarankan, dan mendorong. Dalam proses pembelajaran di kelas X MAN Malang 1 guru hanya menerapkan bentuk advisories menasehati. Berikut ini bentuk tindak tutur direktif advisories yang digunakan oleh guru dalam situasi pembelajaran.

(120) Konteks : Guru menasehati siswa

TTD : Kalian jangan lupa belajar yah buat hari senin UAS, semoga ilmu yang saya berikan bermanfaat dan dapat mengerjakan soal ujian. (Akh/ $\operatorname{Dir}_{6} / \mathrm{F} / 412$ )

Pada konteks (120) di atas guru menasehati siswa agar belajar di rumah dan guru berpesan pada siswa semoga ilmu yang diberikan selama ini bermanfaat, serta siswa dapat mengerjakan soal ujian. Tuturan guru tersebut memberikan gambaran adanya bentuk tuturan direktif advisories yang kuat. Hal itu dibuktikan pada data (Akh/Dir 6 /F/412) dengan pilihan kalimat yang dianggap penting jangan, apabila diperhatikan kalimat ini dimaksudkan oleh guru untuk menasehati. Pada kutipan di atas kata yang menjadi ikon adalah jangan. Pemilihan kata ini dilakukan karena dari deretan kata dalam tuturan guru, kalimat inilah yang mempunyai peran besar untuk mengingatkan siswa belajar. Timbullah bentuk tuturan direktif advisories yang bertujuan menasehati siswa. Tuturan tersebut dituturkan oleh guru pada saat kegiatan akhir sebelum pulang.

\section{KESIMPULAN}

Dalam kegiatan awal proses pembelajaran guru hanya menggunakan bentuk tindak tutur direktif (1) requestives, (2) questions, (3) requirments, dan (4) advisories. Dalam setiap kegiatan inti pembelajaran guru selalu menggunakan tuturan direktif dalam bentuk (1) requestives, (2) questions, (3) requirments, (4) prohibitives, (5) permissives, dan (6) advisories. Tuturan yang sering digunakan guru adalah bentuk tuturan direktif requestives, selebihnya guru menggunakan tuturan questions, requirments, prohibitives, permissives, dan advisories. Hal ini menunjukkan bahwa dalam setiap proses pembelajaran guru selalu meminta siswa untuk aktif dan terlibat langsung dalam proses pembelajaran. Pada kegiatan akhir guru hanya menggunakan bentuk tuturan direktif (1) requestives, (2) questions, dan (3) requirments.

\section{DAFTAR PUSTAKA}

Arifin, B. (1996). Pengantar Awal: Analisis Wacana. Malang: Banyu Media.

Chaer, Abdul \& Agustina, L. (2004). Sosiolinguistik Perkenalan Awal. Jakarta: PT. Rineka Cipta. 
Chaer, A. (2007). Kajian Bahasa: Struktur Internal, Pemakaian, dan Pembelajaran. Jakarta: PT. Rineka Cipta.

Etikasari, D. (2012). Tindak Tutur Direktif Dalam Wacana Kelas (Kajian Mikroetnografi Terhadap Bahasa Guru). Universitas Negeri Malang.

Hamalik, O. (2009). Psikologi Belajar dan Mengajar. Bandung: Sinar Baru Algesindo.

Ibrahim, A. S. (1993). Kajian Tindak Tutur. Surabaya: Penerbit Usaha Nasional.

Ikhawati, N. A. (2010). Kesantunan Menolak dalam Interaksi Percakapan Keluarga
Angkatan Darat di Kompleks Asmil Yonif 514 Kabupaten Bondowoso Kajian Etnografi Komunikasi. Universitas Negeri Malang. Kesuma, T. M. J. (2007). Pengantar (Metode) Penelitian Bahasa. Yogyakarta: Carasvatibooks.

Rahardi, K. (2005). Sosiopragmatik. Yogyakarta: PT. Gelora Aksara Pratama.

Sugiyono. (2010). Metode Penelitian Pendekatan Pendidikan Kualitatif, Kuantitatif, dan R\&D. Bandung: Alfabeta.

Sukmadinata, N. S. (2013). Metodologi Penelitian. Bandung: Remaja Rosdakarya. 